REVISTA DE DERECHO UNED, NÚM. 9, 2011

\title{
DERECHO PROCESAL: TEORÍA E HISTORIA DEL PROCESO CIVIL EN COLOMBIA
}

\author{
Nicolás EnRique Zuleta Hincapié \\ Abogado. Universidad Libre. Especialista en Derecho Penal y \\ Criminología Universidad Nacional de Colombia. Facultad de Derecho, \\ Magíster en Derecho Procesal. Universidad Libre
}

Resumen: El presente texto realiza una caracterización del Derecho Procesal Civil en un contexto histórico, para presentar su concepto y sus alcances, así como la revisión de una tradición jurídica en donde funda sus raíces y se puedan perfilar sus perspectivas. El texto tiene dos momentos para la revisión, el primero un Estado del arte que pretende dar cuenta de los estudios más significativos sobre la evolución de la doctrina procesal en Hispanoamérica y en Colombia, en segundo lugar una aproximación a los conceptos centrales de la teoría procesal civil.

Palabras clave: historiografía derecho procesal civil, normatividad derecho procesal civil colombiano, derecho procesal colonial, derecho procesal republicano, fuentes derecho procesal civil.

Abstract: The present paper is a characterization of the civil procedural law in a historical context for presenting your concept and its scope, as well as a revision of a legal tradition in where he founded its roots and to be able to shape their perspectives. The text have two moments for the review, the first being a State of the art that aims at giving an account of the most significant studies on the evolution of the procedural doctrine in Latin America and in Colombia, secondly an approximation to the central concepts of the theory civil procedure.

Key words: historiography civil procedural law, regulations pro- 
cedural law colombian civil, procedural law colonial, republican sources civil procedural law.

Sumario: I. Introducción.-II. Apuesta metodológica de la investigación.-II.1. Tesis Central.-II.2. Planteamiento y formulación del problema.-II.3. Delimitación.-II.4. Justificación y Aporte fáctico.-II.5. Diseño Metodológico.-III. Hacia un estado del arte sobre la evolución del proceso civil.-IV. La evolución de la doctrina procesal.-V. Hacia una conceptualización del derecho procesal.-VI. La doctrina procesal civil y el concepto de acción.-VII. Las escuelas de la moderna teoría de las acciones civiles.-VIII. Hacia una teoría del proceso civil y su naturaleza.-IX. Conclusiones.-X. Bibliografía.

\section{INTRODUCCIÓN}

El punto de partida de la presente investigación es la evolución del Derecho procesal civil en un contexto histórico, ello implica la caracterización de dicho concepto y sus alcances, así como la revisión de la tradición jurídica en donde funda sus raíces y se establezcan sus perspectivas. Sin embargo, antes de llegar a una teoría del proceso civil, hay que retomar cuestiones como la existencia de un marco histórico para el Derecho procesal general, sus instituciones, los problemas derivados de la identificación de su objeto como ciencia y sus alcances doctrinarios.

En este texto se proponen dos momentos para la revisión, el primero un Estado del arte que pretende dar cuenta de los estudios más significativos sobre la evolución de la doctrina procesal en Hispanoamérica y en Colombia, en segundo lugar una aproximación a los temas centrales de la teoría procesal civil. Algunas consideraciones de orden metodológico se presentan antes de desarrollar los puntos centrales de este capítulo de la tesis doctoral: el problema de investigación y la apuesta metodológica.

\section{APUESTA METODOLÓGICA DE LA INVESTIGACIÓN}

De acuerdo con la estructura metodológica de la investigación se partió de una revisión en torno al problema central (tesis), apoyado en el Estado de arte sobre los antecedentes investigativos en el campo de la historiografía jurídica colombiana. A continuación, se propone una síntesis del diseño metodológico y su relación con los aportes fác- 
ticos del trabajo, su proyección en el campo jurídico y el balance sobre la ejecución de la tesis.

\section{II.1. Tesis Central}

Es posible que la carencia de los estudios analíticos e historiográficos sobre el derecho procesal, haya habido una falencia en términos de eficacia del mismo. Quizá la mayoría de los estudios actuales sobre derecho procesal se hayan dedicado a revisar la aplicación técnica de las normas sustantivas y las presentan de manera "ahistorica» y descontextualizadas de su génesis. Por lo tanto, esta investigación pretende buscar los orígenes genéticos del derecho procesal civil e indagar por los fundamentos y prácticas jurídicas a partir de los cimientos del derecho romano. Para, luego, observar la construcción y práctica del derecho de la España colonial, seguir sus huellas en las nuevas sociedades americanas hasta la segunda mitad del siglo XIX, como sus posibles consecuencias o relaciones con la época contemporánea.

El propósito de esta investigación consistió en describir y analizar dicha evolución normativa para documentar las instituciones de administración de justicia y la práctica judicial, desde el momento en que surge el proceso como un elemento para la aplicación del derecho en los casos concretos. Dicho de otra manera: documentar cómo nace el proceso en el derecho romano y como se extiende por los sistemas jurídicos de la Europa continental, hasta el virreinato de Nueva Granada y más tarde la República de Colombia.

\section{II.2. Planteamiento y formulación del problema}

El problema de investigación se abordó desde una perspectiva de análisis al contexto socio-histórico del derecho procesal civil. Esta perspectiva nos sirvió para detectar que, posiblemente, uno de los problemas en el campo jurídico, como es la eficacia del derecho, en este caso del derecho adjetivo, consiste en aislar las normas adjetivas de su contexto histórico dejando de lado sus raíces y sus procesos evolutivos. Lo anterior, puede hacer vulnerable al derecho procesal frente a su eficacia y por ende se constituye en riesgo para la recta administración de justicia.

\section{- Planteamiento}

En un recorrido por los antecedentes bibliográficos y documentales de la teoría del proceso en Colombia, se observó que no se 
habían realizado investigaciones que de manera sistemática abordaran la evolución y la fundamentación histórica o sociológica de las diferentes instituciones del Derecho procesal. Los aportes de las diferentes fuentes del Derecho y en especial las legales, doctrinales y jurisprudenciales, usadas por los tratadistas para contextualizar las instituciones de la teoría general del proceso, dejan de lado elementos historiográficos, para privilegiar los actos jurídicos -teóricos y prácticos- contemporáneos que se limitan a la aplicación instrumental de las diferentes instituciones procesales, sin revisar sus alcances en el tiempo. La cuestión problemática que se viene exponiendo desde la tesis central es la carencia de los análisis historiográficos en la trayectoria del Derecho procesal en Colombia desde sus orígenes hasta nuestros días, situación que a pesar de ser estudiada hasta 1888, se supone por algunos indicios, que posiblemente hasta comienzos del siglo XXI, tiene el alcance en sus efectos. Ese desarrollo evolutivo podría tener implicaciones en términos de la eficacia en la aplicación del derecho adjetivo actual, por ejemplo, en materia de administración de justicia un seguimiento de las normas que se han expedido en materia de congestión de los despachos judiciales, que parecieran ser un asunto moderno, encuentran antecedentes en normas del llamado periodo de transición normativa de la colonia a la República como el decreto de 3 de diciembre de 1823 sobre «administración de justicia y el decreto de 24 de noviembre de 1826 que promueve la «pronta administración de justicia».

\section{- Formulación}

En atención a dicho contexto en la tesis se revisó el marco conceptual de la teoría jurídica relacionado con elementos conceptuales y se propuso el siguiente interrogante central: $¿$ Cómo ha evolucionado el Derecho adjetivo y la fundamentación de las distintas instituciones, sobre todo las herederas de la escuela española del Derecho procesal civil? Para resolver ese planteamiento, se hizo necesario revisar una serie de eventos de orden histórico y conceptual, que al lado de la pregunta central, se debía responder: ¿Cuál fue la importancia de las fuentes documentales legales, doctrinales y jurisprudenciales del periodo colonial y comienzos del republicano en la formación del Derecho procesal civil colombiano? ¿Qué eventos se convirtieron en antecedentes de la teoría del Derecho procesal civil, en relación con elementos materiales de circulación de teorías, textos y discursos? ¿Cómo operó la estructura legal del proceso y de la administración de justicia en la formación del Estado de Derecho, en la consolidación y eficacia del Derecho procesal civil colombiano? 


\section{II.3. Delimitación}

En la revisión de los conceptos centrales de la teoría del proceso y su importancia para la evolución de las instituciones del Derecho procesal colombiano, fue necesario un recorrido en el tiempo y el espacio que permitió abordar varios momentos de la formación de dicho Derecho teniendo en cuenta las particularidades del período colonial, el pre-republicano y el periodo de la República en donde la formación del Estado de Derecho era presupuesto para la fundamentación de un Derecho adjetivo que facilitara el equilibrio de los poderes y el fortalecimiento de la función jurisdiccional. En este sentido, es preciso destacar que la presente investigación es parte de un proyecto ambicioso que recorrerá la historiografía y bibliografía jurídica de finales del siglo XVIII y gran parte del siglo XIX, pero que en esta fase se concentró en los siguientes derroteros espaciales, temporales y conceptuales:

- Delimitación espacial: se centró en el virreinato de la Nueva Granada y su evolución hacia la instauración de República, en tanto se intentaba explicar el paso de la teoría procesal de la metrópoli política, que era España, hasta la ruptura independentista que propicia el surgimiento del Estado republicano de Colombia.

- Delimitación temporal: tomando como antecedentes la revolución inglesa y la norteamericana la delimitación temporal de la investigación se centró a finales del siglo XVIII y se tomó como hito la Revolución Francesa (1789) por considerar sus postulados como elemento central de la construcción del concepto de debido proceso, en que tiene su asiento formal, la teoría del proceso. Se mostró su desenvolvimiento en el siglo XIX y particularmente en 1886 cuando el Estado Colombiano, surge políticamente como una república con independencia de poderes. Además con la promulgación en 1887 de la Ley 53 como un antecedente del Código judicial de 1912, se extendió hacia el año de 1.888 en donde se producen una serie de normas procesales y se expide el Código de Organización Judicial de la República de Colombia Ley 147 de 1888.

- Delimitación conceptual: Se trabaja en términos de eficacia y se concentró en la mirada teórica sobre las instituciones centrales de la teoría del proceso y su desenvolvimiento en momentos históricos y políticos donde se cimentaban las bases del Estado de Derecho en Europa, para que a partir de la caracterización 
de dichas instituciones en los diferentes Estados, que se empeñaban en formar su derechos autónomos, con influencias comunes de la recepción del Derecho romano presentes en España y que luego se trasplantarían a América, y contribuyeron en la formación del Derecho procesal civil en el marco de las ciencias jurídicas colombianas.

\section{II.4. Justificación y Aporte fáctico}

Esta investigación encuentra su justificación plena en la urgente necesidad de nuevos estudios socio-históricos sobre el derecho -en especial sobre el derecho procesal civil-, a partir de la consideración de que en este campo es donde se han hecho muy pocos estudios que se pregunten por los antecedentes y evolución -normativa, doctrinal y jurisprudencial- de las normas vigentes, atendiendo a un examen sobre su validez y eficacia en el tiempo. El acusado tecnicismo de las normas procesales y su carácter instrumental hace que los ejercicios de limiten a verificar su aplicación presente y para el caso concreto, para relevar los posibles vacíos o lagunas en su interpretación como consecuencia del ejercicio litigioso o de la acción de algunos operadores judiciales, dejando de lado el acerbo que supone sus antecedentes y evolución normativos.

Como parte del proceso de construcción de una teoría jurídica la tesis pretendía romper con el paradigma básico de revisión del Derecho adjetivo como un asunto descriptivo del funcionamiento de las figuras normativas (tipos de procesos, recursos, acciones, pruebas y términos, etc.) en atención a su aplicación judicial contemporánea. Insistimos en que la instrumentalidad del Derecho procesal, muchas veces deja de lado temas como, este, de la evolución legislativa y el proceso de formación de la teoría procesal, para revisar la implementación esas mismas instituciones, sin atender a sus razones y naturaleza histórica. En otras investigaciones que siguen el aspecto socio jurídico el asunto de la evolución de ciertas instituciones procesales se hace con citas y referencias externas para justificar el trasplante legislativo y conceptual de las instituciones del Derecho procesal en nuestro contexto, sin detenerse a mirar su teleología a partir de su génesis.

Si bien, el Derecho adjetivo ha existido siempre como una condición, la aplicación de los Derechos sustantivos, en buena parte de su evolución aquel ha sido un impedimento para la aplicación del sustantivo a los casos concretos en los que se requería una recta y cum- 
plida administración de justicia. En el marco de esta tesis, las hipótesis permitieron caracterizar la transición normativa entre el siglo XVIII y el XIX, para la construcción de las bases conceptuales del Derecho procesal colombiano, desde la estructura ritual heredada del Derecho romano. En estos momentos en los que se pretende implementar la estructura pragmática del Derecho común anglosajón, se requiere con urgencia seguir trabajando en el consolidación del panorama de la tradición procesalista, en la que funda su legitimidad el Estado de Derecho en Colombia.

En medio de la profusión de estudios doctrinales sobre el procedimiento, ésta investigación elaboró una revisión historiográfica, para mostrar el tránsito del Derecho procesal en medio de un sistema monárquico, de concentración de poderes y de violación al debido proceso, hacia un nuevo modelo de libertades que inaugura la Revolución Francesa (1789) y la tridivisión de poderes de los estados republicanos. Luego de verificar como ocurrió la evolución en un sistema pre-republicano, cuyo origen está plagado de contradicciones e incongruencias entre lo formal y lo real, hasta un momento en donde se organiza constitucionalmente la democracia en un sistema republicano, y se convierte en punto de partida de un procesalismo civil más equilibrado, e institucionalmente construido mucho antes de la Constitución de 1886.

\section{II.5. Diseño Metodológico}

La estrategia metodológica para la realización de la tesis permitió seleccionar un método, unas técnicas y unas fuentes de recolección de información, se hizo dividiendo el trabajo en tres momentos: el primero de recolección de información, segundo de selección y sistematización de las fuentes de información y tercero de análisis y procesamiento de los datos teóricos y empíricos producto del trabajo de campo.

Recolección de información: La investigación sobre los antecedentes y evolución normativa del Derecho procesal civil colombiano, se inscribe en una revisión de fuentes documentales, es una tesis que corresponde a una investigación cualitativa, con unas técnicas de recolección de información que determinan un elemento empírico de trabajo de campo en archivos históricos, por lo tanto tiene como objetivo la descripción de carácter historiográfica, en un modelo de investigación socio-histórica, como una herramienta para comprender la naturaleza jurídica de figuras que se remontan al Derecho 
indiano español y a la reproducción de las experiencias procesales de las colonias al nuevo mundo. Desde el marco del Estado monárquico pasando por la ruptura independentista -en la que se construyó el Derecho adjetivo- en el periodo previo a la consolidación de una democracia republicana.

En ese sentido la apuesta metodológica de investigación se centró en el modelo Descriptivo-explicativo, que buscaba dar cuenta del funcionamiento de la Teoría y la Práctica judicial de los tribunales de la época, y su desenvolvimiento en medio de un contexto históricopolítico sin las garantías del debido proceso, que encuentran su máxima expresión en los sistemas democráticos. Se trató de una investigación de orden descriptiva, porque la documentación, sobre todo la primaria, fue un insumo esencial para la construcción de un marco conceptual sobre los fundamentos del Derecho procesal civil contemporáneo, a partir de la evolución de sus figuras en el tiempo.

\section{HACIA UN ESTADO DEL ARTE SOBRE LA EVOLUCIÓN DEL PROCESO CIVIL}

La teoría del Derecho procesal civil colombiano debe ser abordada y estudiada desde la teoría general del proceso y desde la doctrina procesal, sin embargo, el elemento histórico es subsidiario, porque de ninguna manera se pretende una historia del Derecho procesal, en armonía con lo que señala Alcalá- Zamora en su capítulo sobre la trayectoria y contenido de una teoría general del proceso, para establecer sus alcances en relación con la Historia del Derecho:

La teoría general del proceso no es tampoco Historia del Derecho procesal, ya sea de las fuentes, de las instituciones o de la literatura, sin perjuicio de que la segunda, en cualquiera de las mencionadas subdivisiones, especialmente en las dos últimas y de manera particularísima en la tercera, preste inestimables servicios a quien profese la primera, que no podrá moverse con desenvoltura por su campo mientras no domine a fondo el de los conocimientos históricos relacionados con el enjuiciamiento, so pena de levantar castillos en el aire, que se desmoronen al primer soplo de la crítica ${ }^{1}$.

Como antes anotamos y siguiendo los lineamientos de Alcalá Zamora, nuestra investigación no es estrictamente historiográfica, se trata de un ejercicio doctrinal en la perspectiva jurídica, que hace uso

${ }^{1}$ Alcalá-Zamora, Niceto, Estudios de teoría e historia del proceso. México, Iure editores, 2005, pág. 84 . 
de fuentes historiográficas para su documentación. Si bien, nuestro horizonte no es una historiografía del Derecho procesal y especialmente del procesal civil, nuestra preocupación por los fundamentos de la doctrina colombiana, nos pide fijar la atención en una búsqueda sobre sus orígenes en la perspectiva de la ciencia jurídica, más que desde la ciencia histórica. Por lo que insistimos que se trata de una revisión desde la idea de la evolución histórica de la doctrina procesal, mas no una historia sobre la misma, como podría percibirse cuando se acude a fuentes primarias y a recursos de competencia de los historiadores:

(...) la historia del Derecho procesal en particular, de igual manera que la historia del Derecho en general, es, por su finalidad y por su técnica, ciencia histórica y no ciencia jurídica, como, en cambio, lo es la teoría general del proceso, o sea en rigor, la teoría general del Derecho procesal, que sería rúbrica más adecuada, incluso para disipar cualquier equívoco con las acepciones no jurídicas del vocablo «proceso $»^{2}$.

En consecuencia, no se trata de historia del Derecho procesal, pero es claro que en el contexto colombiano, no existen suficientes estudios sobre esta materia que permitan verificar la evolución de la legislación y la doctrina procesal en el tiempo y nos permita unos marcos sociales y económicos, que le confieran un carácter propio a este Derecho. La ciencia jurídica tiene pretensiones de universalidad, pero los problemas del Derecho derivados de su aplicación en el tiempo y el espacio, están íntimamente ligados con el descuido de los doctrinantes a revisar estos contextos por el temor a entrar en el ámbito de otras ciencias como la historia, la sociología o la filosofía.

En ese sentido, siguiendo los lineamientos conceptuales de Alcalá-Zamora en su capítulo sobre la evolución de la doctrina procesal, retomamos las precisiones conceptuales que propone antes de entrar a caracterizar los cinco periodos en los que se sintetiza dicha evolución: periodo primitivo, judicialista, práctico, procedimentalista y procesalista. En primer lugar, este autor afirma que el Derecho procesal como ciencia arranca con las tesis del alemán Oscar Bülow, y muchos de los planteamientos de este autor están representados en cuatro sistemas jurídicos, sintetizados por periodos como: a) Roma, b) Bolonia, el Derecho común y la recepción, c) la Revolución francesa y la codificación napoleónica, d) Bülow (en la doctrina) y Klein (en la legislación).

\footnotetext{
2 Ibíd.
} 
Por otra parte, el autor afirma que en el Derecho procesal visto como un bloque requiere deslindar la evolución de la doctrina procesal de la historia de las instituciones procesales, porque ello supone entender que el proceso como literatura (doctrina) es muy posterior al surgimiento del proceso como realidad (instituciones). Este aspecto es importante, porque nuestra tesis está inscrita en la idea del Derecho procesal civil como una realidad emanada de la realidad en la evolución normativa. El proceso civil surge como realidad a partir de dicha evolución legislativa que va dando forma a las diferentes instituciones en armonía con los desarrollo del poder judicial y de la administración de justicia en la naciente república de Colombia a comienzos del siglo XIX y en su consolidación del mismo.

\section{LA EVOLUCIÓN DE LA DOCTRINA PROCESAL}

Muchos doctrinantes modernos omiten contextos históricos en los que se documente la existencia del proceso. Es así como Alcalá Zamora cita el caso de Von Kries, Chiovenda o Manzini que inician sus estudios sobre la evolución de doctrina procesal en la alta edad media, muchos siglos después de haberse reglamentado el Proceso en el sistema jurídico continental europeo, heredero directo del Derecho Romano, al que pertenece España y por el que llega a los países hispanoamericanos.

Sobre el periodo primitivo, Alcalá Zamora expresa que abarca las primeras manifestaciones sobre la justicia y su funcionamiento, en obras que no necesariamente corresponden al Derecho procesal como tal. El periodo se extiende de las antiguas civilizaciones hasta el siglo XI de la era cristiana. Son varias las obras que se pueden citar al respecto: "Así sucede, por ejemplo, en textos de tipo histórico religioso, cual /(sic) la Biblia; de carácter teatral como Las Avispas de Aristófanes (442 a. J.C.) » ${ }^{3}$ en los que se prefiguran juicios y su puesta en escena.En los textos de esa época no se encuentran rastros de los sistemas procesales organizados, ni siquiera en el mundo griego -con los trabajos en que Ugo Enrico Paoli-, se analiza el juicio a Sócrates, como un texto de carácter procesal. En el mundo romano hay, sin embargo, conceptos procesales-civiles derivados de la tripartición personas, cosas y acciones. El punto de las acciones, lo veremos en aparte sobre la evolución del proceso civil y su naturaleza.

3 Ibíd. pág. 62. 
También se destacan los trabajos de Aristóteles, Cicerón, Séneca y Quintiliano, quienes en sus trabajos sobre Retórica y Oratoria dejan rastros del ejercicio de la profesión de los abogados en el Foro, relacionados con asuntos probatorios. Sobre todos ellos se destacan las Instituciones oratorias de Quintiliano, como la obra de mayor riqueza en la perspectiva procesal.

Alcalá Zamora propone un segundo momento que él llama Escuela Judicialista, en atención al concepto de Juicio, que considera arraigado el lenguaje procesal hispánico y que atiende a dos sentidos: por un lado equivale a Sentencia (juicio judicial sobre el litigio) y por otro a Proceso, éste último es el que él asume y expresa que esta escuela surge en Bolonia. Porque es allí donde según Chiovenda los jurisconsultos se dedican a realizar exposiciones y estudios de sus instituciones, alrededor de los siglos XII y XIII (incluso se remonta a comienzos del siglo XI, con las obra de autores italianos en su mayoría:

(...) entre los que recordaremos a Tancredo en su Ordo iudiciarius (1216) y, sobre todo, a Guillermo Durantes o Durante, autor del célebre Speculumiudiciale (1217), que trata tanto del proceso civil como del penal. Un sector muy característico dentro de la producción de los judicialistas lo constituyen las pequeñas sumas o compendios, que dividen los procesos en fases denominadas tiempos, por lo general entre ocho y diez, y cuya huella sería fácil descubrir en el juicio ordinario de los códigos hispano-americanos, por lo mismo que descienden del Derecho común ${ }^{4}$.

De hecho, según Alcalá Zamora, los judicialistas se movían sobre los postulados del Derecho común, del Derecho medieval italiano e ítalo-canónico en un orden en donde se funden las instituciones romanas con las germanas y las canónicas en las ciudades del norte de Italia. La recepción del régimen de los juicios que será acogido en las naciones europeas entre los siglos XIII a XV, explica su éxito en tres factores: uno científico, determinado por la labor de reproducción de los estudiantes que concurrían en Bolonia y en otras universidades italianas y al regresar a sus países aplicaban los principios del Derecho común en sus actuaciones como abogados o jueces; un factor religioso determinado por el uso que los tribunales eclesiásticos -existentes en todos los países-, hacían del Derecho común antes de la reforma protestante y; finalmente otro político, que llevo a muchos monarcas a preferirlo para superar disputas nobiliarias y fueros locales, como el caso español de Alfonso X y sus Partidas.

\footnotetext{
4 Ibíd., pág. 63.
} 
Se destaca en este periodo la labor de un jurista español que no ha sido suficientemente valorado, el jurisconsulto conocido como Jacobo de las Leyes, o Jácome Ruiz, que fue maestro en la Universidad de Murcia durante el reinado de Alfonso el Sabio, de origen italiano por lo que se supone su formación en Bolonia, y en sus trabajos se funde el Derecho común con el Derecho nacional castellano. Es considerado por eminentes juristas españoles ${ }^{5}$ como uno de los redactores del Código alfonsino y de tres textos de contenido procesal: LasFlores del Derecho, considerado el más importante por ser un borrador o proyecto de la Partida III, y punto de referencia de las instituciones procesales hispanoamericanas, inspiradas en el Derecho romano y traducidas al latín; un resumen de la Partida III, que es una obra de carácter doctrinal y de menor interés que la primera. El tercero Suma de los nueve tiempos de los pleitos, del género de las Epítomes, obra que fue sujeta a plagio en el siglo XV por otra obra denominada Forma lebellandi atribuida a un doctor Infante. Valga la anotación sobre los procesos de plagio, en una práctica bastante común de reproducción de textos en virtud a que no existía un claro principio del Derecho de autor.

El tercer periodo es llamado por Alcalá Zamora Tendencia de los prácticos, una fase que se extiende en España desde el siglo XVI hasta el siglo XIX y que se caracteriza por considerar la revisión de los asuntos del Derecho procesal como un arte y no como una ciencia, por la producción de textos en castellano y al styluscuriae, con predominio de las opiniones y conceptos personales por encima de los preceptos legales. La mayoría de las obras de este periodo se distinguen por sus títulos como Prácticas (forense o judicial) o Praxis, con diferencias entre las que fueron producidas entre los siglos XVI, XVII y comienzos del XVIII, con las de finales de este último y comienzo del XIX. En las primeras, es evidente la falta de método y la confusión entre asuntos procesales con los de Derecho sustantivo, mientras que en las segundas hay mayor claridad en la exposición y sentido crítico de los contenidos.

Muchas figuras que se consideraron creación del procesalismo alemán tienen antecedente en los prácticos como por ejemplo la doctrina de la acción declarativa (Weismann y Wach) que se puede atribuir a un Práctico como Cristóbal de Paz, o incluso otros autores como Antonio Gómez, Diéz de Montalvo, Rodrigo Suárez, Villadiego, Covarrubias, Molina y Febrero. Otra figura es la que establece la naturaleza del proceso como un cuasicontrato, tesis que fue superada por

\footnotetext{
5 Ibíd., pág. 64.
} 
los publicistas pero que en su momento gozó de gran acepción y era atribuida al francés Arnault de Guenyveau, en el siglo XIX. La tesis del cuasicontrato ya antes había sido expuesta por algunos prácticos españoles como Carleval y Salgado de Somoza (más conocido como el conde de la Cañada).

Otro ejemplo sobre el origen de las instituciones del Derecho procesal es la figura de Derecho concursario, con la que se sistematiza la doctrina sobre el concurso de acreedores y que se atribuye al práctico español Francisco Salgado de Somoza en su obra Labyrinthuscrediturum (1649), reconocida por los juristas alemanes, por sentar las bases del principio burocrático o de oficialidad, a diferencia de la doctrina italiana sobre el principio dispositivo y de autonomía de los acreedores $^{6}$.

Además de otras figuras como las Instancias, la tercería y la apelación en el primer periodo del Derecho de los prácticos españoles, se destaca al doctrinante Hevia Bolaños y su obra Curia Philipica (Lima, 1603) que gozó de varias ediciones, igualmente Lucas Gómez y Negro, quien en su obra defiende una concepción pública de proceso apartándose de la concepción predominante en ese periodo de la Práctica forense como arte. Y frente a los prácticos en otros países se destaca el jurista alemán Benedicto Carpzov, descendiente de exiliados españoles, quien en su obra Practica nova imperiales saxonicarerumcriminalium(1635) organizó el modo de actuación del Tribunal de Schoppensthul en Leipzig, basado en las enseñanzas de los procesalistas Julio Clarus y Próspero Farinacius.

De la etapa denominada Procedimentalismo, el autor señala que tiene su origen en Francia, aunque muchos de sus autores no lo sean, las obras y los contenidos de las mismas giran en torno a la organización judicial, al procedimiento y al concepto de competencia, con un carácter expositivo y descriptivo, con muchas falencias aún en desarrollos conceptuales, sobre todo en temas como el procedimiento. Este periodo toma su nombre por la tendencia de las obras del momento a llamarse Procedimientos o de Derecho procesal, es vista como una fase de tránsito entre los Prácticos y Derecho procesal científico:

$\mathrm{El}$ advenimiento del procedimentalismo obedece, a nuestro entender, a una causa política, la revolución francesa, y otra jurídica, la codificación napoleónica, la primera con honda repercusión sobre el enjuiciamiento criminal y la doctrina de la prueba. En efecto, durante la Revolución francesa se forja el proceso penal mixto (por la combi-

${ }^{6}$ Ibíd. pág. 66. 
nación de materiales que realiza) o anglofránces (por la procedencia de los mismos), como consecuencia del movimiento filosófico que la prepara y que los espíritus como Voltaire y Montesquieu hizo volver la vista hacia las instituciones judiciales inglesas, donde se mantenía el sistema acusatorio, que en los demás países había sido sustituido, de Derecho o de hecho por el sistema inquisitivo ${ }^{7}$.

El proceso penal inglés fue adoptado en Francia entre 1789 y 1808 , en el llamado sistema mixto, caracterizado por etapas: la instrucción de tipo inquisitiva y el juzgamiento de tipo acusatorio, con participación del ministerio público y todo ello obligó un replanteamiento de la doctrina que empezaba a quedar rezagada frente a los cambios y permitió a la codificación napoleónica, en la primera parte del siglo XIX separar lo civil (1806) de lo penal (1808), lo sustantivo de lo adjetivo, sin que esa separación se hubiera dado por primera vez en ese contexto:

(...) muchísimo antes de los códigos napoleónicos, el libro II del LiberIudiciorum (siglo VII), la Partida III (1263), el libro III del Fuero Viejo de Castilla (1356), los tres en España, la PeinlicheGerichtsordnung (o Constitutio Criminales Carolina) de Carlos V en Alemania (1532) y, en la propia Francia, las Ordenanzas de Luis XIV (sobre procedimiento civil la de 1667 y sobre enjuiciamiento criminal la de 1670) deslindan y agrupan las normas procesales por separado de los preceptos sustantivos ${ }^{8}$.

Se cita como otra causa de menor impacto, la influencia del filósofo y jurisconsulto inglés Jeremías Bentham, cuya obra tuvo gran influencia en las reformas judiciales de Inglaterra, tanto como en la Revolución francesa, siendo nombrado ciudadano francés por la convención, en atención a sus aportes a la organización judicial y en materia probatoria. En el tema probatorio hay una profusión de obras sobre la Prueba, sin que con ello se quiera afirmar que este es tema de los procedimentalistas, porque es el siglo XIX en donde se producen verdaderos tratados entre los cuales se destacan los del inglés Bentham, el alemán Mittermater y el francés Bonnier. Pero, en relación con los temas generales del procesalismo, más allá de la prueba, se destacan cuatro autores: los franceses Faustino Hélie y Garsonnet, el español José Vicente y Caravantes, y el italiano Mattirolo.

Después del procesalismo se inicia en Alemania el Derecho procesal con carácter científico, y esos orígenes se ubican en 1868 con la obra de Oscar Bülow y su libro La teoría de las excepciones procesa-

7 Ibid. pág. 68.

8 Ibíd. pág. 69. 
les y los presupuestos procesales (die Lehre von den Processcinderenund die Processvoraussetzungen), y que encuentra sus antecedentes en algunos juristas italianos de la edad media como Búlgaro de Saxoferrato y Bernardo Dorna, otros alemanes la conciben (Hegel), otros la sustentan (Bethmann-Hollweg) otros la desenvuelven (Bülow) y proponen variantes y rectificaciones (John, Von Kries, Otto Mayer ${ }^{9}$ ) incluso hay quienes proponen su reemplazo (Goldschmidt).

9 OTto MAYER es considerado como uno de los doctrinantes de mayor relevancia en el Imperio prusiano, y se le atribuye entre otras la sistematización de la teoría de las relaciones especiales de sujeción. LÓPEZ BENíTEZ sobre el particular señala: «...en síntesis, estos autores esbozan dos teorías, que las representan Meyer y Schulze. Para MEYER, todas las notas que LABAND como momentos típicos de la relación especiales de poder (obediencia, fidelidad, poder disciplinario, etc.) se encuentran presentes tanto en las relaciones de poder generales como en las de voluntaria asunción; por el contrario, para ZchUlze los medios de poder disciplinario no pertenecen al Derecho penal general (strafrecht), sino al Derecho del Estado (Staatsrecht). Sobre el tema, vid. WENNINGER, Geschichte..., cit., págs. 118122.

Esta polémica en torno a la naturaleza del Derecho disciplinario será uno de los puntos más controvertidos de la teoría de las relaciones especiales de sujeción, incluso después de MEYER. En este sentido son interesantes las consideraciones que al respecto formula Georg JELLINEK, Sistema deidirittipubblicisubbiettivi (traducción italiana de la segunda edición alemana vertida por Vitagliano), Milán en 1912, pág. 238, nota 1, en donde hace un buen diagnóstico de la realidad existente: «Las diversas categorías del Derecho punitivo no pueden ser señaladas con seguridad según sus fines. Sobre los fines de la pena no se obtendrá jamás la concordia y sin embargo ha observado con razón H. SEUfFERT que el concebir el Derecho de punir disciplinario como una clase del Derecho punitivo general o como una categoría por sí misma, depende aceptar o no la teoría absoluta o relativa del Derecho penal. Una clasificación jurídica puede ser derivada sólo del fundamento jurídico de la facultad punitiva del Estado. Así haciéndolo, resulta un Derecho punitivo que encuentra origen en el imperium del Estado, y otro que se refiere a simples relaciones de dependencia. Tales relaciones pueden estar basadas sobre un contrato de Derecho privado, sobre una subordinación especial derivado de un contrato de Derecho público o sobre una obligación impuesta por la ley; el Estado puede hacer uso de su imperium para crear simples relaciones de dependencia de la constricción a someterse a la relación [...] Donde al contrario una más acentuada relación de dependencia se presenta como relación de una sujeción, allí existe también la constricción a someterse y, en tal hipótesis, no obstante algunas analogías exteriores, el fenómeno no revela ya un poder disciplinario. El soldado, el prisionero, el testigo pueden ser sometidos a ordenamientos punitivos resultantes de su especial relación con el Estado, ordenamientos que son de la misma naturaleza de las penas de policía de Derecho penal general y que, como éstas mismas están dedicadas a completar el Derecho mismo. El poder punitivo del Estado se divide por consecuencia en:

1. Potestad punitiva que resulta del imperium general del Estado.

2. Potestad punitiva que resulta de una especial relación de sujeción.

3. Potestad punitiva que resulta de simples relaciones de independencia.»

Como después analizaremos, JeLlinNeK distingue las simples relaciones de dependencia (en las que no hay obligación de someterse) de las propias relaciones especiales de poder en que este poder si existe». 
El procesalismo científico debe a Bülow ese carácter en virtud a cuatro grandes planteamientos: en primer lugar la independización del Derecho procesal frente al material, que arrancó en Bolonia y se profundizó en la codificación napoleónica con su modelo de legislación separada, segundo, identificar los conceptos primordiales de la disciplina: acción, jurisdicción, proceso, actuación de las partes, entre otros, definiendo, extendiendo y limitándolos.

Alcalá Zamora hace un recorrido por el procesalismo alemán con Bülow (1868), el italiano con Chiovenda (1903), el español Francisco Beceña (1928) y en algunos países latinoamericanos, figuras como Buzaid o Machado Guimaraes en Brasil, Couture en Uruguay, los argentinos Jofré, Alsina y Podetti, el venezolano Loreto, y los mexicanos Castillo Larrañaga, Pallares y Toral Moreno, entre otros autores que han hechos aportes significativos al Derecho procesal científico desde finales del siglo XIX.

En este breve estado del $\operatorname{arte}^{10}$, al lado de la síntesis de Alcalá Za-

En relación con la teoría clásica de las relaciones especiales de sujeción agrega el mencionado autor español: «1. El auténtico constructor de la teoría: OTTO MAYER.

A) EL CONCEPTO DE LA RELACIÓN DE SUJECIÓN ESPECIAL Y SU ÁMBITO

La doctrina alemana suele presentar a OTTO MAYER como el auténtico fundador de la teoría de las relaciones especiales de sujeción, o, al menos, como el primero que reconduce «la separación relaciones generales/relaciones especiales a un sistema jurídico-administrativo». De todas formas conviene matizar que esta elaboración no la efectúa hasta que publica su monumental obra DeutschesVerwaltungsrecht, pues hasta entonces sus tesis son englobables sin excesivos esfuerzos en lo que constituye la communisopinio de un cierto sector doctrinal: la relación especial de poder es también para MAYER el mismo poder del Estado "agravado» y carece, por tanto de sustantividad propia...». LóPEz Benítez Mariano. Naturaleza y presupuestos constitucionales de las relaciones especiales de sujeción. España. Editorial Civitas S.A. 1994. Pág. 64 y 65.

${ }_{10}$ Estado del arte, en el que no se puede dejar de mencionar el pensamiento de Carrara, quien a propósito del origen histórico del juicio señala: «En este último período tuvo que sentirse bastante la necesidad de ordenamientos procesales que limitaran al arbitrio de los que, habiendo sido elegidos jueces, eran elevados a un poder por encima de sus iguales, que al quedar sin frenos podía ser fácilmente peligroso. Así que el juicio criminal, en su forma externa, no asumió fisonomía propia sino en este cuarto periodo. El concepto de justicia no se desconoció nunca ni siquiera en los períodos precedentes; pero en el primer período debía amoldarse a la figura que la ira le impusiera; en el segundo tuvo que asumir los colores del fanatismo, y en el tercero se vio sugestionada por el miedo. De modo que las formas judiciales, arbitrarias en el primer período, convertidas en ritos supersticiosos en el segundo, impuestas de manera autocrática, de acuerdo con las necesidades, en el tercero, solamente en el cuarto adquirieron la noble divisa de ordenamientos racionales, superiores al hombre que juzga a sus propios semejantes. Los códigos de procedimiento penal, ignorados en los primeros períodos, no pudieron nacer sino en el cuarto; y efectivamente nacieron, pues la historia de los hechos corresponde de manera perpetua en el curso de los si- 
mora que contiene un panorama evolutivo doctrinal hispanoamericano, podemos citar la obra del profesor colombiano Guillermo Hernández Peñalosa, quien en la parte cuarta de su obra, donde se dedica al «Derecho procesal» en la estructura del Derecho español e indiano, elabora una síntesis del procedimiento romano y considera que los precedentes de las culturas primitivas de la península, (griegos, fenicios y cartaginenses) no dejaron una huella o sustrato significativo en este Derecho. Una anotación del autor es un elemento clave para la formulación de nuestra hipótesis sobre la naturaleza civilista del proceso, que apunta a considerar que todas las normas de carácter procesal están relacionadas con el deseo de justicia para la satisfacción del Derecho vulnerado al lesionado, parten del reconocimiento de un Derecho de parte y de la posibilidad del interesado en obtenerlo:

El Derecho civil sustantivo y sus reglas de aplicación, o sea, su materia procesal civil, preponderaron de tal manera, que influyeron en todo procedimiento aplicable al carácter del Derecho lesionado. (...) prácticamente, en toda esa época se mantuvo en el Derecho público romano la supremacía de los Derechos del Estado frente a los particulares, pues no se necesitaba de nadie para hacer justicia no había quién se lo impidiera ni autoridad ante la cual se le obligaba a comparecer. Por el contrario, la autoridad existía en referencia a los particulares y, aunque en período relativamente tardío, fue la encargada de hacer justicia a quien por sus propios medios no podía alcanzarla ${ }^{11}$.

En el caso colombiano podemos destacar de obra de autores como Azula Camacho ${ }^{12}$, que si bien no hacen historiografías extensas

glos al progreso de las ideas y al desarrollo de la razón humana». CARRARA, Francesco, Programa de Derecho criminal. Parte general volumen II Bogotá. Editorial temis.1957. Pág. 268 y 274.

${ }^{11}$ Hernández Peñalosa, Guillermo, El Derecho en Indias y en su metrópoli, Bogotá, Editorial Temis, 1969, pág. 449.

${ }_{12}$ A propósito del Derecho procesal en España señala el autor colombiano: «En los primeros tiempos, en la península Ibérica coexistieron dos legislaciones distintas, que afectaron a diferentes grupos sociales, consecuencia del fenómeno acaecido en Europa, de la invasión de los bárbaros al Imperio romano. En efecto, se menciona el Código de Tolosa o Código de Eurico, elaborado durante el reinado de Eurico, rey de los visigodos y "primer rey independiente de España» entre los años 466 y 484, que re una recopilación de las normas consuetudinarias y que a la vez fue el ordenamiento de los visigodos. De otra parte, se cita el Breviario de Aniano, de carácter netamente romano y que regía para los iberos, adoptado por Alarico, sucesor de Eurico.

Como aconteció en los pueblos europeos, con el correr de los tiempos, después de la invasión al imperio, se produce la fusión de los ordenamientos -el de los visigodos y el de los españoles- para dar lugar al Fuero Juzgo o Libro de los jueces, promulgado en el año 654, y que es una de las grandes obras jurídicas.

La Edad Media trajo consigo la fase denominada del proceso común. En ella desaparece la legislación unitaria para dar paso a las de cada señor feudal, que igualmente conservaron la denominación de fueros, por lo cual a esta etapa se le suele llamar fo- 
sobre el proceso civil, les dedican capítulos a realizar breves exposiciones sobre los momentos más significativos de la evolución del Derecho procesal manteniendo sobre la estructura del Derecho romano, el Derecho en sistemas normativos europeos, especialmente Alemania, Italia y Francia, el Derecho español que se traslada al nuevo mundo y en el caso colombiano desde el Código Judicial de 1912.

\section{HACIA UNA CONCEPTUALIZACIÓN DEL DERECHO PROCESAL}

Para el Diccionario de la Real Academia española, la idea de pro-

ral. La importancia y poder de los monarcas sobre los señores feudales se manifiesta también en el campo judicial: Alfonso X, el sabio, unifico las disposiciones forales en un cuerpo denominado siete partidas, cuya parte tercera se ocupó en lo relativo al procedimiento.

Situación similar se presentó en América, en donde la legislación española se encontraba dispersa en cédulas reales. Por orden de Felipe II, en 1567, se elaboró una recopilación, completada posteriormente por la Recopilación de las leyes de Indias de 1680 ».

Y agrega sobre el Derecho procesal en Colombia: «Con la independencia no se creó un nuevo ordenamiento jurídico. Los nacientes Estados adoptaron su propio régimen en el aspecto político, pero no en lo tocante a las otras normas, las cuales mantuvieron su vigencia hasta bastante tiempo después. Fue así como el art. 188 de la primera constitución (la de 1821) se dispuso que el ordenamiento español continuara rigiendo mientras no se expidieran preceptos expresos. Solo en 1845 se produjo una codificación de las normas vigentes, mediante la Recopilación Granadina, obra de don LINO DE Ромво, que fue adicionada cinco años después y que tuvo influencia española.

Al crearse los Estados Soberanos que integraron el Régimen Federal, cada uno expidió su propia legislación. El de Cundinamarca, mediante la ley 29 de 1858, regula lo referente a la organización jurisdiccional y el procedimiento civil. Esta ley fue de la chilena, que a su vez lo era de la de Enjuiciamiento Civil español de 1855.

En 1872 se adopta como Código de la Unión el de Cundinamarca, que, además, ya regía en varios Estados. Al consagrarse el Centralismo, se acogió como Código de la nueva República de Colombia, el de Cundinamarca, mediante la ley 57 de 1887.

Todos estos ordenamientos, cuyo texto realmente fue el mismo, provenían de una raigambre netamente española y acorde con los principios del proceso común y los liberales, caracterizados por el sistema escrito y la tarifa legal.

Numerosas pero intranscendentes reformas en cuanto a los principios se refiere, se efectuaron a la codificación adoptada en 1887. Para unificar esas reformas y ponerse a tono con la evolución doctrinaria, se quiso adoptar un nuevo ordenamiento procesal, y se encargó de su elaboración al insigne juez antioqueño doctor IsAMEL ARBELÁEz. Ese Código, conocido con el nombre de su autor, fue sancionado mediante la ley 103 de 1923, pero rigió muy poco tiempo, en razón de que recogió muchos aspectos ajenos a la tradición jurídica nuestra, por lo cual, ante el clamor unánime, fue suspendido, para en su lugar regresar al derogado, en virtud de la ley 26 de 1924». Azula CAmacho, Jaime, Manual de Derecho procesal civil, parte general. Bogotá D.C., Editorial Derecho y ley Ltda. 1979. Pág. 1-3. 
ceso está referida en sus acepciones más amplias a: proceso (Del lat. processus) entendido como:

1. m. Acción de ir hacia adelante.2. m. Transcurso del tiempo.3. m. Conjunto de las fases sucesivas de un fenómeno natural o de una operación artificial.4. m. Der. Agregado de los autos y demás escritos en cualquier causa civil o criminal.5. m. Der. Causa criminal. en infinito.1. m. Acción de seguir una serie de cosas que no tiene fin.fulminar el .1. loc. verb. Der. Hacerlo y sustanciarlo hasta ponerlo en Estado de sentencia. Vestir el .1. loc. verb. Der. Formarlo con todas las diligencias y solemnidades requeridas por Derecho ${ }^{13}$.

Se observa en las distintas acepciones relativas o no a la noción jurídica del término, un sentido de temporalidad y de secuencia. Para el jurista Leo Rosemberg la palabra proceso proviene de procedere (processus) que significa: marchar, avanzar hacia un fin determinado, un acontecer de una determinada clase. En tanto procedimiento es un proceso de acciones humanas, es decir una serie o conjunto de acciones humanas que se refirieren unas a otras y que están recíprocamente encaminadas para lograr un propósito. En ese orden de ideas aclara estas concepciones para el Derecho en la perspectiva histórica:

En sentido jurídico se usa la palabra processus, a partir de la Edad Media (primero en Derecho canónico), muchas veces con el aditamento iudiciarius o iudicii, y significa el procedimiento para la reclamación y la prosecución de los Derechos ante los tribunales. Este término no era corriente entre los romanos, que hablaban de lis, iudicium, iurgium ${ }^{14}$.

De acuerdo con lo anterior el proceso civil será el «procedimiento judicial en los litigios de Derecho civil», en virtud de la forma como la administración de justicia del Estado regula las cuestiones jurídicas en materia civil. De acuerdo con Rosenberg la palabra proceso sirve para designar un procedimiento particular, entre dos partes con motivo de una relación jurídica entre ellas:

1. El proceso está sujeto a una doble consideración: de un lado como procedimiento, es decir, como la totalidad de las actuaciones del Tribunal y de las partes, que se ejecutarán sucesivamente teniendo cada una a la anterior por presupuesto y a la siguiente por consecuencia; pero dirigidas todas al logro de la tutela jurídica judicial y unidas por este fin común; o como relación jurídica, es decir, como la

13 Diccionario de la Real Academia Española, Bogotá, Santillana, 2009.

14 Rosenberg, Leo, Tratado de Derecho Procesal Civil. Buenos Aires, Ed. Jurídicas Europa-América, 1955, pág. 1. 
totalidad de las relaciones jurídicas procesales producidas entre el Tribunal y las partes.

2. Todo proceso es una relación jurídica, es decir, una relación entre los sujetos procesales regulada jurídicamente; no sólo lo es el procedimiento se sentencia o resolución, sino también los procedimientos de ejecución, embargo, monitorio, etc. ${ }^{15}$.

En lo estrictamente jurídico, al hacer una revisión de los conceptos centrales que se retoman como referencia, se deben destacar las concepciones sobre Derecho procesal y sus matices. Pallares Portillo, anota que la palabra proceso viene del Derecho canónico y deriva de la expresión Procedo, término que equivale a avanzar» en cita de Menéndez Y Pidal, que lo define como: «la coordinada sucesión de actos jurídicos derivados del ejercicio de una acción Procesal y que tienen por objeto obtener una decisión jurisdiccional» ${ }^{16}$.

Pallares recoge el concepto de Piero Calamandrei para quien proceso es: «una serie de actos coordinados y regulados por el Derecho Procesal, a través de los cuales se verifica el ejercicio de la jurisdicción». Por su parte Ugo Rocco lo define como: «conjunto de actividades del Estado y de los particulares con las que se realizan los Derechos de éstos y de las entidades públicas que han quedado insatisfechas por la falta de actuación de la norma de que derivan ${ }^{17}$.

Para Couture y a propósito de la expresión proceso, anota:

En la primera acepción del proceso como secuencia éste constituye una acción humana que se proyecta en el tiempo; es una situación análoga a la que existe entre el ser y el devenir; los actos procesales devienen proceso. En su segunda acepción, en tanto relación jurídica, el proceso es un fenómeno intemporal e inespacial; un concepto, un objeto jurídico ideal, construido por el pensamiento de los juristas. En su tercera acepción, como expediente o conjunto de documentos, el proceso es un objeto físico; ocupa un espacio en el mundo material; es una cosa» ${ }^{18}$.

De acuerdo con Calamandrei, el ejercicio de la jurisdicción permite ejercer el Derecho procesal. El principio de Jurisdicción tiene el mérito histórico de surgir de la Revolución Francesa y de acuerdo con el maestro Hernando Morales Molina: «por medio de la jurisdic-

15 Ibíd., pág. 8.

16 Pallares Portillo, Eduardo, Diccionario de Derecho Procesal Civil, México, Porrúa. 1996, pág. 642.

17 Ibídem.

18 Couture, Eduardo, J., Fundamentos del Derecho procesal civil, tercera edición. Buenos Aires. Ediciones Depalma. 1981. Pág. 123 
ción, el Estado interviene en las relaciones de los particulares para declarar e imponer el Derecho en cada caso, es decir, para dar a cada cual lo suyo (suum quique tribuere), obrando con sujeción a la Ley, pues todo Derecho en la actualidad se reconoce en nombre de ella y no en el de cualquier autoridad o persona» ${ }^{19}$.

Para Francesco Carnelutti ${ }^{20}$ es necesario distinguir proceso de procedimiento. El primero es «el conjunto de todos los actos que se realizan para la solución de un litigio; mientras que Procedimiento es

19 Hernando Morales Molina, Curso de Derecho Procesal Civil. Bogotá: ABC, 1991, pág. 746.

20 Sobre las diferencias entre el proceso penal y el proceso civil, resulta interesante traer a colación el pensamiento de Carnelutti, quien al respecto señala: «Tratemos de penetrar un poco más en esta apariencia. Ciertamente, la riqueza, a simple vista, es más agradable que la pobreza; pero, ¿y en el fondo? Sin duda, el proceso civil en el noventa por ciento de los casos, es un proceso de poseedores; cuando uno de los dos no posee, aspira por lo menos a poseer. Es el proceso de lo mío y de lo tuyo. La apuesta del juego es la propiedad. Y cuando se trata de lo mío y de lo tuyo los hombres no se dan tiempo a reposo. En el proceso penal, en cambio, ¿de qué se trata? La respuesta, que en lugar de la propiedad, pone la libertad, le viene a cualquiera a la mente; pero; ¿estamos seguros de no caer en un equívoco al usar de esta solemne palabra? Nueve de cada diez de los que responde así, entienden que el riesgo es el de volverse a su casa o de quedar recluido en prisión; y en esta última hipótesis hacen consistir la pérdida de la libertad. El primero de los cometidos de la ciencia del proceso penal es, en cambio, el de enseñar a invertir ese razonamiento; esto es, el primero de los conceptos que ella tiene que aclarar, y acaso construir, es el concepto de libertad. Nos daremos cuenta entonces, el día en que se cumpla este cometido, que hasta entonces como en tantos otros sectores, la realidad ha sido vista por nosotros al revés: el reo no es un libre a quien la condena le quita la libertad, sino un siervo a quien se le restituye o por lo menos trata de restituírsela. La libertad, pues, es verdaderamente la apuesta del proceso penal, pero en sentido directamente inverso al perezosamente considerado por la opinión común: al juez penal se le pide, como al juez civil, algo que nos falta y de lo cual no podemos prescindir; y es mucho más grave el defecto de libertad que el defecto de propiedad. El juez penal, como el juez civil, reconoce o debería reconocer a cada cual lo suyo; esto es suser en lugar de su haber.

En esta fórmula se ha determinado por desarrollar la distinción profunda entre los procesos, civil y penal, y no entre los dos derechos: en el civil se discute acerca de haber y en el penal acerca del ser. Y así se ha aclarado el porqué del interés de los hombres por el uno y del desinterés por el otro. Somos siempre aquellos quihabentoculos et non vident, habentaures et non audiunt [que tiene ojos y no ven, tiene oídos y no oyen]. ¿Quién de nosotros llega a apreciar más el ser que el haber? Hasta el buen joven, obediente a todos los mandamientos de la ley de Dios, cuando el Maestro lo invitó para conquistar el ser, a dejar el haber, le falto la fuerza para seguirlo. De los dos verbos que contienen todo el sabor de la vida, uno, que habría de ser el siervo, ocupa el corazón de los hombres el puesto del dueño; el otro, que debería ser el dueño es tratado, en él, como siervo.

Después de esto, ¿podrá sorprender a nadie a ciencia de la ciencia del proceso penal le haya sido reservada la suerte de la cenicienta?». CARnELuTti Francesco. Cuestiones sobre el proceso penal. Buenos Aires. Ediciones jurídicas Europa-América. 1961. Pág. 18 y 19. 
la combinación de los diversos actos que se deben realizar para la solución de un litigio. Proceso sirve para denotar un máximo; procedimiento un mínimo. En la formación del primero contribuye la idea de conjunto; a formar el segundo la idea de combinación. (sist. IV396 Carnelutti)» ${ }^{21}$. Para Guisseppe Chiovenda el proceso civil es: «el conjunto de decretos coordinados para la finalidad de la actuación de la voluntad concreta de la Ley (en relación a un bien que se presenta como garantizado por ella), por parte de los órganos de la jurisdicción ordinaria» (Chiovenda, Inst. 1-38) 22 $^{22}$

Según Parra Quijano, la palabra proceso:

Surge en el Derecho canónico y se deriva del procederé, término equivalente a avanzar (Menéndez y Pidal). Este el proceso "como la coordinada sucesión de actos jurídicos derivados del ejercicio de una acción procesal y que tiene por objeto obtener una decisión jurisdiccional». Piero Calamandrei define el proceso como «una serie de actos coordinados y regulados por el derecho procesal, a través de los cuales se verifica el ejercicio de la jurisdicción». Para Ugo Rocco, el proceso «es el conjunto de las actividades de los órganos jurisdiccionales y de las partes necesaria para el desenvolvimiento de la función jurisdiccional civil».

Según el diccionario de la Real Academia Española, proceso significa: (Proceso del latinprocesus) "acción de ir hacia adelante; transcurso del tiempo, conjunto de las fases sucesivas de un fenómeno".

Proceso significa marcha, avance hacia adelante, progreso, transcurso del tiempo. Acción de ir en busca de determinado fin, acontecer de determinada clase. Así, se habla de un proceso químico, de un proceso de desarrollo, de un proceso de curación.

Según Eduardo Couture, se puede definir el proceso en una primera acepción como una secuencia o serie de actos que se desenvuelven, progresivamente, con el objeto de resolver, mediante un juicio de autoridad, el conflicto sometido a su decisión ${ }^{23}$.

De acuerdo con Fábrega Ponce el Derecho procesal es la: «Rama jurídica que regula el ejercicio de la función jurisdiccional del Estado, que incluye la integración y organización del órgano judicial, su competencia los procedimientos, los Derechos y obligaciones de las partes y del juez, así como sus respectivas cargas y expectativas y los efectos de los actos jurisdiccionales» ${ }^{24}$.

21 Pallares,op. cit.

22 Ibid., pág. 643.

23 Parra Quijano, Jairo, Estudios de derecho procesal, tomo I. Bogotá D.C. Ediciones librería del profesional. 1980, pág. 9.

24 FÁbrega Ponce, Jorge, Diccionario de Derecho Procesal Civil. Cuesta, G., Carlos. Diccionario de Derecho Procesal Penal. Bogotá: Plaza \&Janés, 2003, pág. 1424. 
Fábrega cita entre otros autores a Jaime Guasp, para quien el Derecho Procesal no quiere decir otra cosa de Derecho referente al proceso sino el: «conjunto de normas que tienen por objeto el proceso o que recaen sobre el proceso» Igualmente, cita a la definición de Eduardo Couture: «Rama del saber jurídico que estudia en forma sistemática la naturaleza del proceso civil, su Constitución, desenvolvimiento y eficacia.» Y Véscovi quien lo define como: "Conjunto de normas que establecen los institutos del proceso y regulan su desarrollo y efectos, también la actividad jurisdiccional $»^{25}$.

Es nuevamente Pallares, quien cita el Derecho Procesal civil como: «el conjunto de normas jurídicas relativas al proceso jurisdiccional», tomando como partida para la definición amplia, una caracterización del Derecho procesal de Carnelutti como: «el conjunto de normas que establecen los requisitos y efectos del proceso (...) recibe el nombre de Derecho formal porque la reglamentación que hace del proceso, se realiza mediante formas» por su esencia es Derecho instrumental porque a diferencia del Derecho sustancial, no resuelve los conflictos de intereses, sino que establece los órganos y procedimientos que permiten resolverlos. (sist. I. págs. 81 y 82 ) $^{26}$.

De acuerdo con Carnelutti ${ }^{27}$, son características del Derecho procesal, que permiten identificar cuando una norma es de carácter procesal, en relación con su contenido y finalidad, luego de examinar su existencia aun cuando en la práctica se encuentren diseminadas en diferentes ordenamientos : a) El Derecho procesal es Derecho público, reglamenta la actividad de un órgano del Estado como el poder judicial y realiza un interés público como es obtener paz social mediante la justicia, b) La mayoría de sus normas son de carácter instrumental y no sustancial o material, c) Posee normas materiales de las que se derivan Derechos subjetivos y las obligaciones correlativas a los mismos, d) Por ser Derecho público sus normas son de obligatorio cumplimiento, e) está relacionado con el Derecho constitucional y el Derecho administrativo, f) La finalidad de las normas procesales es la composición de los conflictos de intereses que se ventilan en el juicio, y los conflictos de intereses procesales (incidentes), g) En el Derecho procesal es donde con mayor fuerza se hace sentir la necesidad de completar la obligatoriedad de las Leyes y su eficacia práctica correlativa, mediante sanciones y estímulos morales y económicos, h) El Derecho procesal es en gran parte de sus disposiciones

\footnotetext{
${ }_{25}$ Ibid.

26 Pallares, op. cit., pág. 245.

27 Ibíd., pág. 246.
} 
formalista, en el sentido de establecer rituales de procedimiento, i) El Derecho procesal no es meramente adjetivo y complemento del Derecho material, porque los dos se complementan y el primero goza de autonomía relativa (cfr. Doctrina de Goldschmidt), j) El Derecho procesal está unido al llamado Derecho judicial (conjunto de normas concernientes a la organización y funcionamiento del poder judicial), k) El Derecho procesal puede ser considerado como un todo, o sea, como un conjunto unitario y sistemático de normas jurídicas que reglamentan el proceso en general.

Pero si bien, el Derecho procesal tiene unas características que lo harían común independientemente de las ramas o áreas del Derecho en las que se encuentre, Fábrega, analiza el concepto de Teoría General del Proceso como un intento doctrinal de elaborar una teoría única y sistemática que abarque todos los procesos. Anota como se consideraba que existía una diferencia radical entre proceso civil, penal, laboral y contencioso-administrativo en atención a la naturaleza de la relación material sobre la cual versaba, dejando de lado el carácter autónomo del proceso. Por ello la Ciencia del Proceso, ha construido una teoría general en la que se estudian las normas procesales con criterio unitario en sus principios. Dicha teoría considera que en todos los procesos hay unos elementos comunes: a) demanda, denuncia $\mathrm{u}$ otro elementos introductivo o peyorativo, b) los sujetos, c) relaciones jurídicas entre sujetos del proceso, d) objeto (pretensión, excepción) y factores supervinientes, f) causa de la pretensión, g) procedimiento, h) fallo, i) modos de impugnación. Fábrega anota que son muchos los autores que sostienen la importancia de construir una teoría General del proceso, «entendida como el conocimiento científico de los principios y conceptos que son comunes a toda categoría de proceso o procedimientos» ${ }^{28}$ y que ello representa problemas insalvables cuando existen teorías particulares ${ }^{29}$.

${ }^{28}$ FÁBREgA, pág. 1248.

${ }_{29}$ Pero si de procesos se trata, en sentir de Bernard, el mayor proceso de la historia, el más importante proceso internacional de todos los tiempos -y para algunos, el más discutible-, se desarrolló estando ausente al acusado número uno. Sólo fueron juzgados y condenados sus comparsas, sus ayudantes más directos. Ese proceso se abrió el 20 de noviembre de 1945, en Nuremberg, una de las cunas de derrotado nazismo. Fueron necesarias 403 audiencias para que el tribunal oyera a 33 testigos de cargo y a 61 de descargo, y entender sobre 141 declaraciones escritas, antes de llegar a la clausura de debates.

Aquel proceso marcaría el término efectivo de la Segunda Guerra mundial. Adolf Hitler está ausente -al parecer muerto en su bunker de Berlín-, pero Goering, Hess, Ribbentrop, Keitel, Rosenberg, principalmente se sientan en el banquillo de los acusados. Alguno de ellos fue capturado después de una verdadera caza del hombre a través de una Alemania agonizante y arruinada. 
En esta tesis doctoral los conceptos de acción y jurisdicción, serán esenciales para la evolución normativa del Derecho procesal civil, sobre todo, porque la mayoría de las instituciones que se pueden apreciar en el recuento histórico están relacionadas con las figuras centrales del poder judicial y la administración de justicia, y por otro lado las acciones procesales y los diferentes tipos o formas de los juicios.

\section{LA DOCTRINA PROCESAL CIVIL Y EL CONCEPTO DE ACCIÓN}

En la evolución histórica de los diferentes conceptos de la doctrina general del Derecho procesal, los tratadistas han abordado varios problemas nominales, incluso el que tiene que ver con el concepto de Derecho procesal, como una acepción reciente del siglo XX, como una ciencia, así como las nociones de teoría del proceso, acción civil, y proceso civil. Sin embargo, la teoría del Derecho procesal debe distinguir su naturaleza civilista, de su fundamentación penal, a la luz de ciertas teorías que han distinguido su objeto y sus alcances.

La teoría de proceso está directamente asociada con la teoría de las acciones procesales. En el capítulo sobre la evolución histórica hemos pretendido una síntesis de la evolución de las acciones desde el Derecho romano justinianeo hasta su recepción en Europa. En esta parte nos ocuparemos de la génesis de las acciones y el juicio antes de su recepción en España, de su llegada en el mundo colonial neogranadino y de su paso a la República.

En efecto, para algunos autores la teoría del proceso civil gira alrededor de tres conceptos: proceso, jurisdicción y acción, siendo el último el más complejo de definir y que ha producido más polémicas a partir de las cuales se construye la moderna ciencia del Derecho procesal:

La naturaleza de la acción «es el punto neurálgico de la doctrina procesal y la encrucijada entre el Derecho material y el judicial». Hasta mediados del siglo pasado la acción era un tema exclusivo del Derecho civil. Se concebía a la acción: 1) la potestad inmanente del Derecho subjetivo de reaccionar contra su violación; 2) el Derecho mismo

Speer, uno de los acusados, al reconocer la culpabilidad del régimen de Hitler, declararía: "Este proceso es necesario... Aun bajo una dictadura, crímenes tan horrendos exigen una responsabilidad común. Parapetarse detrás de la obediencia a las órdenes recibidas, sería una excusa inadmisible». MichaL, Bernard, El proceso de Nuremberg, tomo 1, Círculo de amigos de la historia, 1973, pág. 13. 
en su tendencia a la actuación; 3) un Derecho nuevo que nace de la violación del Derecho subjetivo y cuyo contenido es la obligación del adversario de hacer cesar la violación ${ }^{30}$.

La acción era vista como una «duplicación del Derecho subjetivo cuyo estudio correspondía al Derecho civil, mientras que el procedimiento se ocupaba de las formas de actuación en el juicio, el concepto de acción en el proceso no era suficientemente desarrollado para el Derecho procesal. En consecuencia, los pasos iniciales para ubicar el carácter procesal de acción, desprendiéndolo de viejo Derecho civil, se dan en Alemania porque en esta tradición se fundía el concepto de la Actio romana (sobre el que había muchas discusiones) y la Klage, entendida como klagerechto Derecho de querella, con la diferencia en que la Actiose dirigía contra el deudor obligado y la klage contra el Estado:

Windscheid publica en 1856 su obra La acción en el Derecho Romano desde el Punto de Vista del Derecho Actual, en el que denomina pretensión a la dirección personal que toma el Derecho cuando es violado y propone reemplazar por este término la actio romana. Pero Muther, apoyado en la tradición de la Klage, presenta a la acción como un Derecho contra el Estado, en la persona de sus órganos jurisdiccionales a los cuales el individuo reclama protección jurídica. La polémica y la elaboración doctrinaria prosiguió con Oscar Bülow, José Kohler, Dernburg y otros y, sobre todo con Adolfo Wach, de quien se titula alumno Chiovenda. En Wach la acción es el «Derecho de aquel a quien es debida la tutela jurídica» concebido como un Derecho autónomo dirigido contra el Estado y el adversario ${ }^{31}$.

Un hecho cambiaría el rumbo de la moderna ciencia del Derecho procesal. En febrero de 1903, el profesor Giuseppe Chiovenda Leyó en la Facultad de Derecho de la Universidad de Bolonia, su Prolusión el Curso de Derecho Procesal Civil que denominó L Azionenel Sistema deiDiritti y aunque no se la ha dado el reconocimiento actualmente, es a partir de ese momento que la acción no es considera Derecho material, y que el procedimiento puede ser estudiado con autonomía y no como glosa del Derecho sustantivo, como lo hacían los exegetas para tener el estatuto de una rama del Derecho con jerarquía científica:

Chiovenda concibe la acción como un Derecho potestativo, entendido por tal un Derecho al que no corresponde una prestación, «que tiene por contenido un puro poder jurídico y no un deber ajeno», es

30 Aftalión R. Enrique, José Vilanova, y Julio Raffo, Introducción al Derecho. Buenos Aires: Abeledo Perrot, 2004, pág. 926.

31 Ibid., pág. 927. 
decir, «que tiende a la modificación del Estado jurídico existente». La acción es pues «el poder jurídico de dar vida a la condición para la actuación de la voluntad de la Ley». El concepto de Chiovenda no ha sido seguido por la doctrina posterior, pero en trono del maestro y fundador toda una pléyade de estudiosos se dieron a la tarea de sustituir los viejos tratados de procedimientos por nuevas producciones inspiradas en su obra y siempre continuando la tarea de concebir procesalmente, y no desde el punto de vista del Derecho civil, las instituciones fundamentales ${ }^{32}$.

La doctrina posterior siguió la tendencia a considerar la acción como un Derecho de la parte al que le corresponde un deber del Estado. En una posición que había propuesto Degenkolb y que luego Goldschmidt la definió como acción o «Derecho de obrar procesal» (con su contenido de pretensión de sentencia) y como un «Derecho público subjetivo» dirigido contra el Estado para obtener la tutela jurídica mediante sentencia que favorezca al accionante ${ }^{33}$.

32 Ibid., págs. 928-929.

${ }^{33}$ La teoría del Derecho público subjetivo se le atribuye particularmente a Karl Friedich Von Gerber y George Jellinek. Posteriormente Laband y Mayer desarrollaran la teoría de las relaciones especiales de sujeción, para justificar el poder del Monarca respecto de los funcionarios y militares. A propósito de nuestro estudio, resulta interesante la articulación que realiza Laband, entre el Derecho disciplinario y el Derecho civil en el contexto prusiano. Así, destaca el autor: "...Así mismo se ha llegado a afirmar que el Derecho disciplinario es una expresión del Derecho civil. Para Laband: “...el concepto de Derecho disciplinario no puede alcanzarse por su relación con el Derecho penal tal como venía haciéndose, sino por su relación con el Derecho civil (...) puesto que el Derecho disciplinario es el correlato de unas relaciones contractuales y de unas relaciones de poder. Lo decisivo es que las consecuencias disciplinarias de la infracción de los deberes funcionariales no se basan en el poder sancionatorio público del Estado sino en la supremacía de servicio o funcional, o sea, en las relaciones de poder que median entre el Estado y sus servidores. Las sanciones disciplinarias no son, por tanto, penas en el sentido de Derecho penal sino medios para mantener el orden y la disciplina dentro de las relaciones de servicio y para asegurar el cumplimento de los deberes oficiales"..."

Sobre el particular destaca GARCía MACHO:

"..."...Laband, que se ha preocupado de reflexionar ampliamente sobre el tema, configura la relación funcionarial como una relación contractual, en la que el funcionario se consagra al Estado y asume obligaciones especiales. Sin embargo, la infracción de los deberes del funcionario no constituye una violación del contrato, sino una falta, y el cumplimiento de sus obligaciones no significa la ejecución del contrato sino el cumplimiento de las obligaciones contraídas de lealtad y obediencia. A cambio de esta relación especial de sujeción originada, el Estado protege al funcionario y subviene a sus necesidades. En este tipo de contrato hay un elemento obligatorio (relación de sometimiento o dependencia) y otro voluntario. Este último existe porque la realización del contrato la hace voluntariamente el funcionario; es decir, asume las obligaciones desde su libre albedrío. La parte obligatoria del contrato está determinada por las obligaciones concretas (lealtad y obediencia) que el funcionario contrae. La parte obligatoria prevalece, y eso se manifiesta especialmente en el poder disciplinario..."

Tal posición doctrinal, no obstante la legítima pretensión de separar el Derecho 


\section{LAS ESCUELAS DE LA MODERNA TEORÍA DE LAS ACCIONES CIVILES}

Como se ha propuesto a lo largo del trabajo el tema de las acciones civiles es un elemento central en la teoría del proceso civil. Luego de hacer una breve síntesis de su evolución desde el Derecho romano hasta bien entrado el periodo colonial, retomamos los planteamientos de Eduardo Couture, quien en su introducción al proceso civil se pregunta por las acciones y expresa que cuando surge su interés por el tema -a comienzos del siglo XX- comenzaba la difusión en América de las escuelas italiana y germana. La primera naciente y la segunda su antecedente. Para Couture hasta ese momento el tema había sido visto por la tradición las doctrinas de las escuelas españo$l^{34}$ y francesa:

La escuela española, especialmente en sus escritores de los siglos XVIII y XIX, no había prestado a este tema una particular atención. Obras enteras de excelente calidad, algunas realmente magníficas, no contenían desarrollos especiales sobre el tema, y en todo caso se limitaban a hacer exégesis del precepto clásico actio nihil aliudestquamiuspersequendi in indicio quodsibidebetur (pr. Inst. De Actionibus, 4,6) Una traducción casi literal de este adagio se encuentra aún en algunos códigos hispanoamericanos. Solamente los escritores españoles el siglo XX se han tomado un interés especial por este tema, y en sus argumentos constituyen, en todo caso, una exposición, y algunas veces

disciplinario del derecho penal, desconoce que el Derecho disciplinario es en esencia Derecho público que, enmarcado dentro del Derecho sancionador de Estado conforme al iuspuniendi, en cuanto a capacidad, poder o facultad otorgada a la Administración, para determinar correctivos disciplinarios, previo el agotamiento de unas fases del expediente disciplinario rodeadas de las garantías cuyo contenido tiene claro raigambre constitucional, recoge toda una serie de principios y procedimientos, diferentes de aquellos propios del Derecho privado, en donde impera el principio de autonomía de la voluntad y cuyo acercamiento haría diluir las garantías en comento.

Seguramente obedece la posición a la formación iusprivatista del autor. Sobre el particular comenta CASTILLO BLANCO, que el Derecho constitucional de este Imperio alemán fue elaborado sobre todo por LABAND, catedrático de Estrasburgo, quien inicia su formación en el Derecho privado y sólo posteriormente dirigió sus estudios al Derecho público...» FORERo SALCEDo, José Rory, Estado constitucional, potestad disciplinaria y relaciones especiales de sujeción, Bogotá D.C., Instituto de Estudios del Ministerio Público. 2007, págs. 164 y 165.

${ }^{34}$ En la escuela española, la doctrina del procedimiento civil tuvo un gran exponente en Jacome Ruiz (siglo XIII conocido como el maestro Jacobo de las leyes), de quien se dice fue autor del texto de la Partida III «Doctrinal que compuso el Maestre Jacobo de las leyes para Bonajunta su fijo», publicado actualmente como Obras del maestro Jacobo de las leyes, jurisconsulto del siglo XIII, Madrid: 1924, por Rafael de Ureña y Smenjuan. 
una prolongación avanzada, de las ideas de las escuelas alemana e italiana ${ }^{35}$.

De acuerdo con la escuela francesa «la acción es un Derecho en movimiento ${ }^{36}$, similar a una manifestación dinámica del Derecho, sin que existiera una distinción entre Derecho y acción. Sin Derecho no existe la acción. Cita a Demolombe para quien la Ley incurre en un pleonasmo cuando habla de Derechos y acciones. Para que una acción existiera debían concurrir cuatro elementos: Derecho, interés, calidad y capacidad.

La influencia de la escuela alemana, llega a nosotros por la lectura directa de los italianos y de los modernos españoles. Couture señala como a comienzos del siglo XIX, surge una disputa sobre los alcances de la Actio romana, distinguiéndose el concepto de acción de pretensión, estableciéndose, en consecuencia una fisura entre Derecho procesal y Derecho sustancial. Para 1885 el jurista alemán Wach publica un manual (Handbuch des deutschen) donde la idea de acción en justicia está bastante definida, la acción es un Derecho autónomo separado del Derecho sustancial, es un instrumento para hacer valer el Derecho, pero no es el Derecho mismo. Cita la obra de Degenkolb de 1877 (EinlassungzwangundUrtëslsnorm) para quien el demandante, si quería tener acción debía estar «sinceramente asistido de Derecho» ${ }^{37}$.

En la escuela italiana el tema de las acciones tiene como documento fundamental la conferencia de Chiovenda titulada Lázionenel sistema deidiritti ${ }^{38}$, dictada a comienzos del siglo $\mathrm{XX}$, en la que se funde la dogmática de la escuela alemana y las antiguas tradiciones del Derecho romano, manteniendo en esencial el pensamiento de Wach. Para Chiovenda «la acción es autónoma, concreta» pertenece solo a quienes tienen la razón en ejercicio de un Derecho potestativo. A él se opone la denominada tesis abstracta de Carnelutti, más cercana a Degenkolb. En esta escuela también se destacan jurista como Calamandrei y Redenti ${ }^{39}$.

35 Couture, Eduardo J., Introducción al estudio del Proceso Civil. Buenos Aires: Ed. De Palma, 1949, pág. 7.

36 Ibíd., pág. 9.

37 Ibíd.

38 Conferencia publicada en Sagi di Dirittoprocessualecivile, Roma, 1930, t. 1, traducida al español Colección Ciencia del proceso, Buenos Aires: 1949.

39 Para Morales Molina «Sobre las diversas escuelas que han predominado en el Derecho procesal, Carnelutti presenta cuatro etapas de la evolución del Derecho procesal de Italia, que puede reducirse a tres:

a) Período exegético en que prevalecieron los comentarios respecto al estudio en 


\section{HACIA UNA TEORÍA DEL PROCESO CIVIL Y SU NATURALEZA}

Existen algunos antecedentes en la doctrina procesal colombiana que apuntan a relevar la naturaleza civilista del proceso. Teniendo en cuenta que los postulados de las legis acciones romanas, operaron hasta bien entrado el periodo republicano y teniendo en cuenta que el proceso romano, tuvo un carácter esencialmente privado ${ }^{40}$, en la medida en que las controversias se resolvían atendiendo a los intereses de las partes.

Hoy en día, el Derecho procesal civil descansa sobre una base eminentemente constitucional. En efecto, El proceso de constitucionalización del Derecho, a partir de las constituciones de la segunda posguerra mundial, así lo determinara y de ahí la relación entre organización y procedimiento. Al respecto Hesse señala:

(...) la idea de los derechos fundamentales de participación y de los derechos sociales fundamentales no puede tener en la actualidad sino una importancia limitada para la eficacia y la protección de los derechos fundamentales; igualmente, sólo de forma limitada serían adecuadas otras normas constitucionales definidoras de tareas del Estado para hacer frente a los desafíos que resultan de los cambios apuntados (número marginal 25) siendo así, resulta mucho más importante una

orden riguroso de los artículos del Código y la interpretación basada en la intención del legislador.

b) Período de las teorías particulares, en que la investigación se orienta hacia un sistema que busca los principios relativos a las instituciones, siendo principal obra la de Mattirolo; después Mortara estudió el proceso considerado por sí solo.

c) Período de la teoría general del proceso, en que la exégesis da paso a la dogmática y se hace sentir influencia de la escuela alemana.

Se llama también período de Chiovenda, quien sistematizó los principios de dicho movimiento y estableció los vínculos del proceso y del Derecho sustancial, y luego del propio Carnelutti, quien sintetizó los principios del proceso en general y estudió el proceso dentro de la teoría general de derecho.

Alcalá Zamora y Castillo enumera cuatro períodos en el estudio del Derecho procesal en España:

1) De los judicialitas, por ser el juicio con sus sujetos y su división en tiempo o fases el concepto destacado. 2). De los prácticos, que se caracterizan por la prevalencia de la cuestión practica sobre la sistematización procesal. 3). La procedimentalista, inspirada en la escuela francesa, acompañada por la italiana, cuyos autores no alcanzan a situarse todavía en el plano de las otras ramas jurídicas, y siendo mucha la exégesis, mantienen casi siempre sus concepciones privatistas, 4). El procesalismo científico, influido por Chiovenda, con base en la escuela científica de la ciencia procesal e inspirado en la ciencia alemana». Morales, M. Hernando, Curso de Derecho procesal civil, parte general, sexta edición. Bogotá. Editorial ABC, 1973. Pág. 16-19.

${ }_{40}$ Cfr. Hernán FaBio LóPEz, Evolución histórica del Derecho procesal civil colombiano, pág. 32 . 
conexión que hasta se ha tenido bastante menos en cuenta: la relación que guardan entre sí derechos fundamentales, organización y procedimiento. Esta relación, que en la más reciente jurisprudencia del Tribunal constitucional ha venido a ser cada vez más destacada, tiene importancia genérica para la efectividad y la garantía de los primeros; pero además permite mejor que a través de los derechos de participación y de las normas enunciadoras de tareas del Estado adaptarse a los cambios producidos en la efectividad de los derechos fundamentales en el Estado moderno, y contribuye a compensar los déficits de la garantía jurídico-fundamental de libertad.

Para poder cumplir su función en la realidad social, los derechos fundamentales precisan en mayor o menor grado un desarrollo concretador por el ordenamiento jurídico (cfr. número marginal 62): para que la situación jurídica regulada como derecho fundamental se torne real y efectiva en el seno de la sociedad, se hace necesario por doquier que no solamente establecer regulaciones materiales más minuciosas, sino también poner en pie formas de organización y normas de procedimiento. Más imperativa se hace aún esta necesidad en las condiciones presentes, en las que la libertad humana depende del apoyo, la previsión y distribución por el Estado y en las que cada vez más se imponen el deslinde, la limitación y la ordenación recíproca entre los ámbitos de libertad (cfr. número marginal 25). Frecuentemente se acreditan la organización y el procedimiento con medios para alcanzar un resultado conforme con los derechos fundamentales y, de este modo, asegurarlos eficazmente también bajo las actuales circunstancias.

En la medida en que los derechos fundamentales precisan considerablemente de organización y procedimiento, actúan al mismo tiempo sobre el Derecho administrativo y el Derecho procesal, los cuales contribuyen de esta suerte a realizarlos y asegurarlos. Esto resulta evidente en la relación con derechos fundamentales cuyo objeto inmediato es la garantía de principios administrativos de organización o procesales, como libertad de asociación (art. 91 GG), el derecho a un juez determinado por ley (art. 101 GG), a ser oído en juicio (art. 103.1 GG), o con los requisitos y garantías procesales que establece el art. 104 GG para las formas de limitación y privación de la libertad. Pero también los derechos fundamentales materiales actúan sobre el procedimiento. De ahí que el Tribunal constitucional haga hincapié en una aplicación del Derecho procesal conforme a los derechos fundamentales. Además, interesándose por la eficacia y aseguramiento de estos derechos, ha ido planteando especificas exigencias jurídico -procesales a partir de los derechos fundamentales materiales, concretamente la necesidad de una protección jurídico-fundamental efectiva a la que el individuo tiene derecho ${ }^{41}$.

41 Benda, Mainofer, Vogel, Hesse, Heyde, Manual de Derecho constitucional, Barcelona. Marcial Pons, ediciones jurídicas y sociales S.A. 2001. Pág. 101-104. 


\section{CONCLUSIONES}

Como consecuencia del desarrollo del problema de investigación, más allá del capítulo anterior y de los objetivos cumplidos, se pueden establecer las siguientes conclusiones:

- Existe claridad sobre el momento histórico donde se produce la ruptura con la tradición jurídica heredada del Derecho monárquico español, pero no de otras escuelas de fundamentación de las doctrinas del Derecho como la francesa, la alemana y la italiana. Que se consideran referencias transversales para las instituciones hispánicas.

- El Derecho procesal civil y sus instituciones sufrieron un proceso de evolución histórica con unos caracteres propios en la formación del Estado colombiano, con origen en las tradiciones del Derecho colonial.

- La identidad del Derecho colombiano y en especial la de la teoría del Derecho procesal civil encuentra su origen y fundamento mucho antes de la promulgación de la Constitución del 1886.

- La teoría del proceso civil y la práctica judicial tienen implicaciones particulares en medio del sistema colonial de un Estado monárquico y un periodo de maduración en una democracia formal, que no real en la época republicana.

\section{BIBLIOGRAFÍA}

Aftalion, Enrique et al. (1994), Introducción al derecho, Conocimiento científico, historia de las ideas jurídicas, teoría general del derecho, Teoría General Aplicada. Buenos Aires: Editorial presencia.

Alcalá Zamora, Niceto (2001), Estudios de teoría e historia del proceso. México: Jurídica Universitaria.

- Nuevos estudios de derecho procesal. (1980) Madrid: editorial Tecnos.

Calamandrei, Piero (1962), Derecho Procesal Civil. Buenos Aires: E.J.E.A.

Campos Rivera, Domingo (2003), Derecho Procesal Laboral. (Conflictos del Trabajo) Bogotá: Temis.

CAPPELETti, Mauro (1973), El proceso civil en el derecho comparado: las grandes tendencias evolutivas. Buenos Aires. 
- Las Sentencias y las normas extranjeras en el Proceso. (1968) Buenos Aires: Ediciones Jurídicas Europa-América, 284 págs.

CARRARA, Francesco (1957), Programa de derecho criminal. Parte general volumen II Bogotá. Editorial Temis.

Cardona Galeano, Pedro Pablo (1982), Manual de Derecho Procesal Civil. Procesos declarativos. Bogotá: Señal editora.

Carnelutti, Francesco (1971), Derecho Procesal Civil. Buenos Aires: E.J.E.A.

- Cómo se hace un proceso. Bogotá: Ed Temis.

- (1961) Cuestiones sobre el proceso penal. Buenos Aires. Ediciones jurídicas Europa-América. 1961.

Bernard, Michal (1973), El Proceso de Nuremberg. Círculo de amigos de la Historia.

Botero Angulo, Jorge Humberto y otros (1994), Grandes temas del Derecho Constitucional Colombian. Medellín: Biblioteca Jurídica Dike.

Benda, Mainofer, Vogel, Hesse, Heyde, Manual de Derecho constitucional. Barcelona. Marcial pons, ediciones jurídicas y sociales S.A. 2001.

Forero SAlCEdo, José Rory (2007), Estado constitucional, potestad disciplinaria y relaciones especiales de sujeción. Bogotá D.C. Instituto de estudios del Ministerio Público.

FRIEDE, Juan (1965), Descubrimiento y conquista del Nuevo Reino de Granada. Historia Extensa de Colombia, Bogotá: Ediciones Lerner.

García MÁYnez, Eduardo (1940), Introducción al estudio del derecho. México: Porrúa.

Garcia Morelos, Gumesindo (1998), El amparo de Hábeas Corpus, estudio comparativo México-argentina. México ABZ editores.

García Unda, Arturo (2005), Lecciones de Historia del Derecho. Quito.

García Villegas, Mauricio, Apuntes sobre codificación y costumbre en la historia del derecho colombiano. En: Precedente (2003), págs. 98124.

Hernández Peñalosa, Guillermo, (1969) El Derecho en Indias y en su metrópoli. Bogotá: Editorial Temis.

Hinestrosa, Fernando (1980), Derecho Civil Primer año, Lecturas. Bogotá: Universidad Externado de Colombia. 
Huber Olea, Francisco (2005), Derecho Romano I. México: Iure editores.

IBAÑEZ DE AldECoA, Alfonso (1954), Meditaciones sobre la cientificidad dogmática del derecho procesal. Buenos Aires: Ediciones Arayú.

IRIBARREN, Juan Antonio (1938), Historia general del derecho. Chile: Ed. Nascimento.

Isaza SerRano, Carlos Mario (1996), El personero municipal, segunda edición, Bogotá D.C. Ediciones jurídicas Gustavo Ibañez.

LoPÉz Blanco, Hernán Fabio (1993), Instituciones de Derecho Procesal Civil colombiano. Bogotá: ED. ABC, 6 edición.

López Sandoval, Ciro (1996), Lecciones de Derecho Procesal Civil. Bogotá: 2 tomos.

Morales Molina, Hernando (1991), Curso de Derecho Procesal Civil. Bogotá: ABC.

- (1973) Curso de Derecho procesal civil, parte general, sexta edición. Bogotá. Editorial ABC.

Pallares Portillo, Eduardo (1996), Diccionario de Derecho procesal Civil. México: Porrúa.

- (1962)Historia del Derecho Procesal Civil mexicano. México. UNAM.

Parra Quijano, Jairo (1992), Derecho Procesal Civil. Tomo 1, Parte general, Bogotá: Temis.

- (1980) Estudios de derecho procesal, tomo I. Bogotá D.C. Ediciones librería del profesional.

Rosenberg, Leo. (1995) Tratado de Derecho Procesal Civil. Buenos Aires: Ed Jurídicas Europa-América. 